\title{
Burning effigies with Bakhtinian laughter
}

\author{
Florian Göttke \\ University of Amsterdam/Dutch Art Institute \\ fu.goettke@gmail.com
}

\begin{abstract}
The hanging or burning of effigies as an expression of dissent is a well-established genre of playful political protest. It is enacted in a variety of ways, accessing the conventions of various traditional rituals and social practices, and can function either as a progressive force demanding change, or repressively in seeking to enforce the existing order. Building on a close reading of media images of effigy protests from over the world, I relate the employed strategies of reversal and debasement and the grotesque aesthetics of these dummies to Bakhtin's concept of the carnivalesque. I trace the different kinds of laughter that emerge during the effigy protests and explore the complicated relationship between laughter and violence inherent in these performed images of violent death.
\end{abstract}

Keywords: effigy performance, political protest, Bakhtin, carnival laughter, violence.

\section{Burning effigies: humorous images of violent death}

Almost every United States president has been hanged or burned as an effigy at some point in their careers. President George W. Bush's effigies were hanged and burned in demonstrations the world over; papier-maché statues of him were toppled in a mocking repetition of Saddam Hussein's bronze likeness in Baghdad to protest the war in Iraq. The situation was not very different for President Barack Obama. In fact, his first effigy had already appeared even before his presidential inauguration during a protest in Lebanon, thereby making it plain that the derisive target was not so much the person of the president, but US politics in general. However, in the period before President Obama's re-election in 2012, which coincided roughly with Halloween, his effigies appeared hanging in trees or suspended from makeshift gallows in a number of places across the United States. The reaction to these hanging effigies was markedly different as they invariably triggered associations with lynching and in the media sparked discussions about racism rather than failed presidential policies. While some of the apparently naïve makers of the effigies seemed to be surprised and embarrassed when confronted by this reading and quickly removed the effigies from public view, others refused to recognize this 
painful historical link to actual violence directed against African-Americans and hid behind the argument that their image-making and display was their right to "freedom of expression".

Effigy-burning in public has become a distinct and widespread element of the performance of protest - insulting and ridiculing the high and mighty, revelling in their grotesque appearance and theatrically staging their downfall. Although at face value these various protests seem quite similar, since they use the same kind of symbolic, humorous performance of violent death to object to certain policies, the associations and connotations they trigger can be very different. In this essay I will discuss the relation between using effigies as signs of political protest and the concepts of grotesque realism and the carnivalesque. In Mikhail Bakhtin's writings, carnival laughter is the expression of communal vitality, which encompasses life and death and symbolically configures debasement and violence as necessary aspects of the human life cycle. Burning effigies with the specific goal of expressing political opposition poses a different set of analytical complications than the symbolic violence of carnival. Considering the insulting and debasing nature of the effigies, these images of violent death must be characterized as divisive rather than inclusive and it depends very much on one's position in the conflict, if one even finds the effigy performance laughable (Ferguson \& Thomas 2008: 294; Smith 2009: 150). The relationship between laughter and violence inherent to the effigy executions appears to be especially delicate, for its specific constellation seems to determine if and to what degree various audiences react with laughter or outrage. Because Bakhtin's concept of the carnivalesque uniquely combines an aesthetics (the grotesque) with a strategy (reversal and debasement) and the effects of this practice on the social body, applying his concepts will make it possible to trace the continuities and discontinuities of the practice through time and space and enable discussing the entanglement of humour and violence in these political protests.

\section{Methodology and data}

A note on the data used in this article and the method of analysis is in order at the outset. The images have been largely sourced from international news websites, regional news websites, digital newspaper archives, databases of image agencies, historical archives, thematic websites dealing with local history, online collections of digitized books, databases of scholarly articles, and personal blogs. This manner of collecting data has limiting consequences for the research, since it privileges events that are recent, deemed to be of international relevance or historically significant, while local practices without a wider political impact tend to remain invisible. More unfortunately, my collecting is limited to events posted with comments and tags in the languages known to me (English, German, Dutch, and some Portuguese and Spanish) and largely reflects a Western European and US perspective, even when I examine events in other cultural contexts. When necessary, I have collected additional data focused on specific countries, by searching in specific archives, employing native speakers for the search, and by conducting interviews with informants.

For this article I will largely ignore the mediality of the photographs and focus on their content. I will apply methods drawn from visual anthropology, examining the body of images to detect patterns of the practice related to behaviours, attitudes, spatial configurations, and group formations, obviously restricted by my own limited knowledge of the cultural contexts. I will also conduct a close reading of a number of photographs that are exemplary for their depiction of distinctive variations of the practice, and consider their contexts. Subsequently I will focus on an 
iconological reading of the grotesque representations that are produced to demean, insult, and ridicule, and I investigate the different expressions of the carnivalesque they contain.

I rely on a general readability of images, which is supported by theories in visual studies, semiology, iconology, art history, and visual anthropology. Likewise this readability is assumed by the protesters, who make the effigies with the intent to communicate visually through the symbolic performances as well as through the mediated images. Because of the polysemic nature of images in general and the excess of information in photographs in particular, I consider readings that go beyond the protesters' initial messages as legitimate as well (Edwards and Morton 2009: 7).

\section{Modes of effigy protest}

To make clear how the performances function in the political and social field and how carnivalesque strategies and laughter are engendered or muted, it is necessary to first sketch the variety of constellations that these protest performances establish between the active protesters, the targeted figure, the immediate audiences, and the ones reached through the media. At first glance, the practice of burning effigies in political protests seems quite uniform the world over, as the resulting images look strikingly similar: a group of protesters gather on the street and express their political opposition by hanging or burning a makeshift representation of a human figure. However, a closer investigation reveals that the practices have several different genealogies: two originate in traditional non-political effigy practices and one in the appropriation of formal legal proceedings. These prototypical practices have different structures, which, even after transforming into symbolic political statements, inform the way the effigy burnings are enacted and how the practices affect the communities in question. I have identified three modes of performing an effigy protest, which I will outline in the following paragraphs.

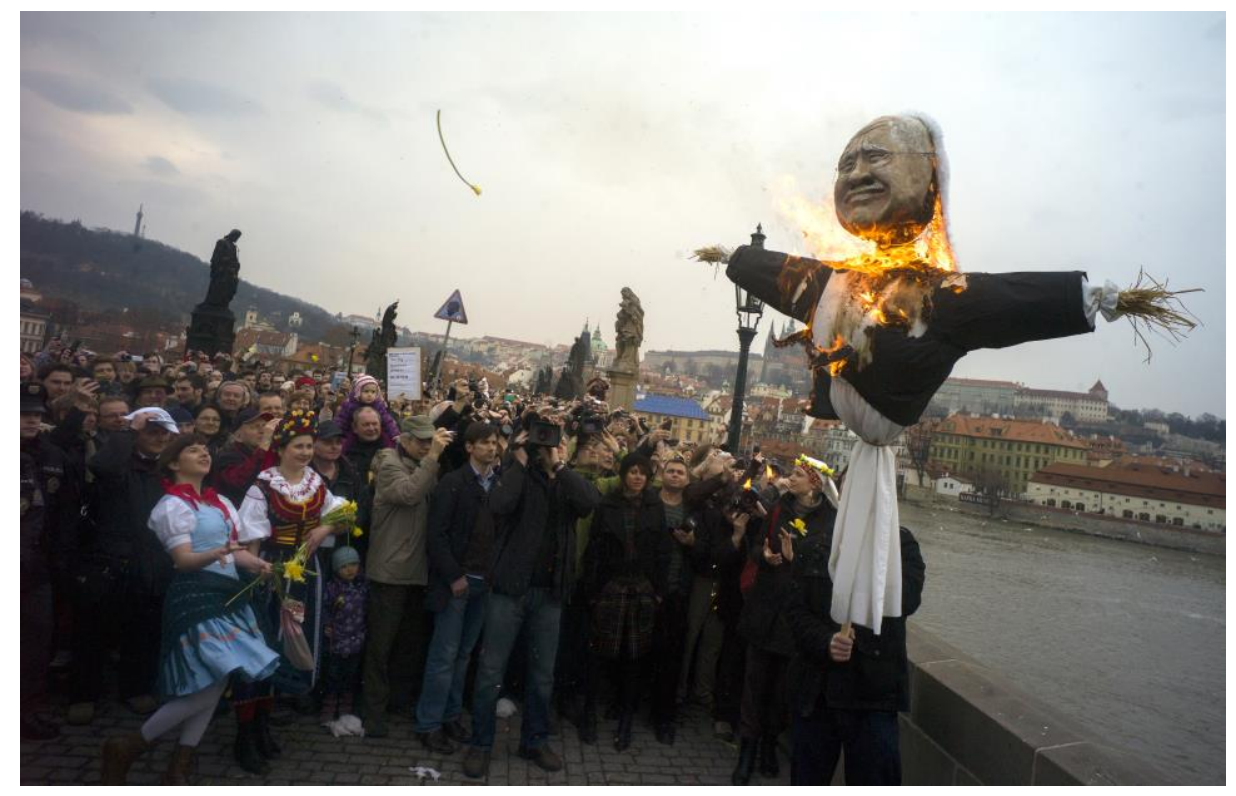

Figure 1. Protesters burn an effigy of the outgoing president Vaclav Klaus in the guise of traditional winter goddess Morena on his last day in office (7 March 2013, Prague, Czech Republic, photo: AFP/Michal Cizek). 
In the photograph in Figure 1, we can see a burning effigy of the outgoing president Vaclav Klaus, held aloft on a stick by a protester at the edge of the Charles Bridge over the Vitava River with the Mala Strana neighbourhood and the castle in the background. The figure's upper body resembles a torso with outstretched arms dressed in a white shirt and a dark jacket, the "uniform" of the politician. Yet the lower body is missing, and straw can be clearly seen protruding from the openings where the hands would be. The larger-than-life-sized head has been carefully shaped from papier-maché, its face frozen in a painful smile. Forming a crowd on the bridge in the centre and to the left in the image is a motley group of protesters - or rather participants in the ritual burning of the puppet. On the last day of his presidency, Vaclav Klaus was substituted for Morena, the goddess of winter and death, whose effigy is traditionally burned and drowned at the end of March to celebrate the coming of spring.

This first mode of performing an effigy protest is based on a wide range of rituals of purification that mark the end of the old year and the beginning of the new and which exist all over Europe, in countries with a Hindu culture, and in many former European colonies. ${ }^{1}$ As with Carnival described by Bakhtin, these rituals celebrate cyclical time - nature's death and rebirth and often dolls representing the old and exhausted energies of the past year are symbolically burned to cleanse the air and usher in the new life cycle. When the ritual is adapted to express discontent and demand political or societal change, the general figure of evil is replaced by a concrete political figure, blamed for the misfortune. In this kind of public, carnivalesque group performance, the celebratory spirit of the ritual still governs the political protest at least to some degree. In the example of Vaclav Klaus, the protesters retained almost all elements of the ritual burning and drowning of Morena, goddess of winter, such as the time of year, the location on the bridge, the burning and subsequent drowning of the effigy, as well as traditional costumes and music. Since the protesters were not demanding the ouster of a sitting ruler but were simply celebrating the expiry of an elected official's term as he leaves office, this protest was rather benign and the performance celebrated the life cycle inherent in the democratic process and expressed the hope for change in Czech politics. 


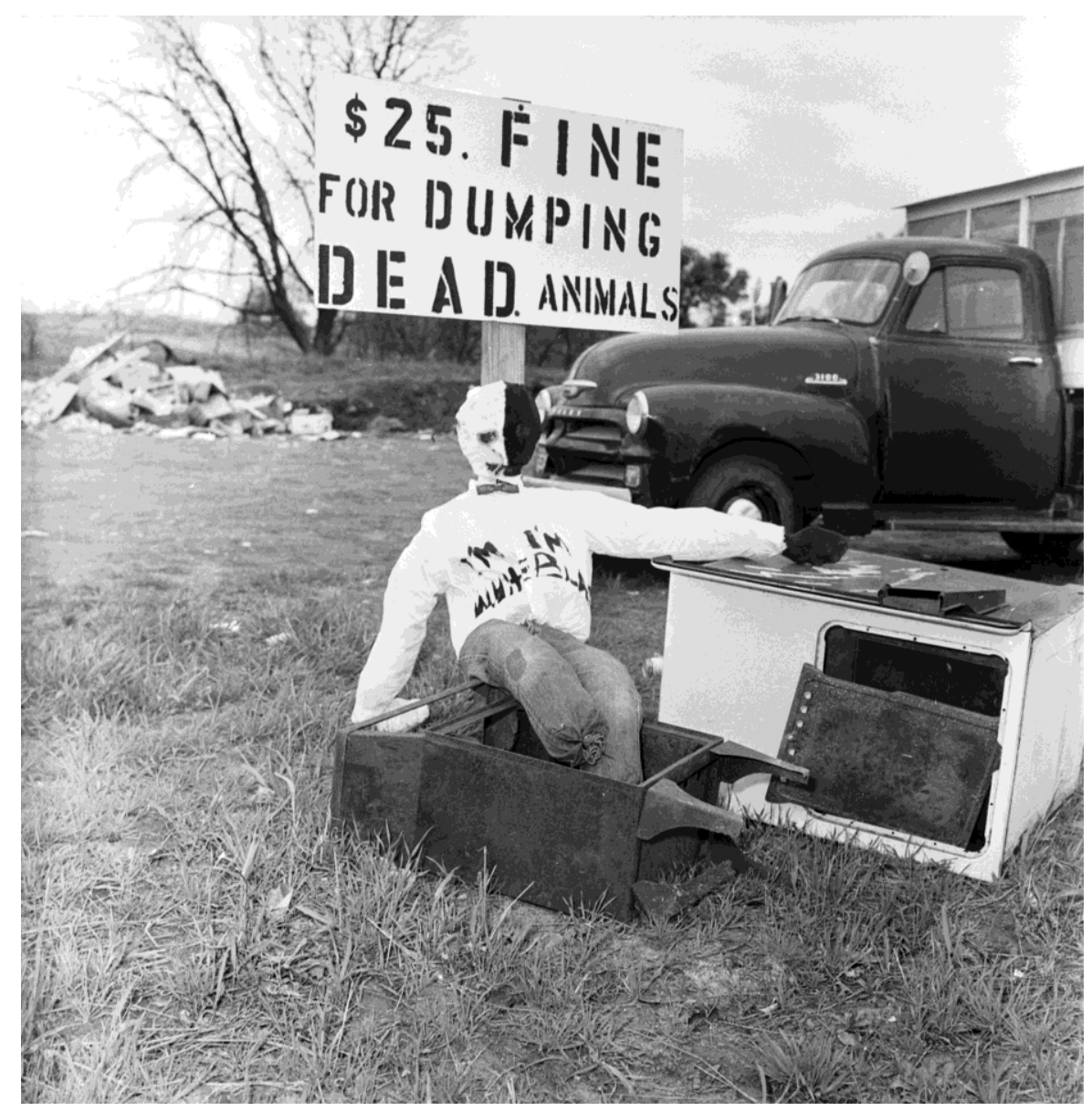

Figure 2. An effigy of author John Howard Griffin lies discarded on a garbage dump after it had hung for half a day on a traffic light on Main Street (2 April 1960, Mansfield, Texas, USA, photo: Bob Bain/Collection of University of Texas at Arlington).

This second mode of performing an effigy protest is derived from practices of traditional popular justice - the informal (often vigilante) enforcement of communally held norms and values. Common in many European countries, these practices were often transferred to their colonies. Historically, popular justice was most often enacted in response to violations of a community's customs regarding marriage and sex. A perpetrator would be publicly humiliated by the performance of a mock concert (rough music) in front of his or her house: an assembled group loudly beating on pots and pans for three consecutive nights (Thompson 1992: 3). But chastisement could also include the physical abuse of the perpetrator or the parading, trial, and punishment of an effigy (Muir 1997: 110; Rooiakkers 1995: 7-11). During the American Revolution, adaptations of popular justice, including the hanging and burning of effigies, were used for political purposes against British officials, tax collectors, and British loyalists, who were forced to acknowledge the new revolutionary order or leave the area.

In this same vein, John Howard Griffin (see Figure 2) was censured and ostracized for his transgression of the (then legal and customary) racial divide. John Howard Griffin wrote the book Black Like Me in 1960 detailing his experience of racial discrimination while travelling disguised as a black man in the Deep South of the United States. His book became a bestseller and in the wake of its gaining publicity, in his hometown of Mansfield, Texas, his effigy was 
hung on Main Street, a cross was burned in front of the local school for black students and a neighbourhood bar put up a sign reading "No albinos allowed". His effigy eventually ended up on the local garbage dump, where a newspaper photographer took a picture of it propped up against a sign announcing a fine for dumping dead animals (Griffin: 154-56). The effigy's head and face are divided into a white and a black half, its shirt underscoring this message with a text reading: "I'M WHITE / I'M BLACK". All these signs emphasize Griffin's transgression of the racial divide as an unacceptably ambiguous state: the effigy characterizes him as half black and half white, the albino sign as black with an abnormal white appearance, while the photograph associates him with an animal carcass rather than a human corpse.

The protesters aimed to prevent change and uphold the social norms that were undergoing progressive attack by the civil rights movement. His effigy represented an individual supporter of the subjugated black community inside Southern society and it was not merely a sign of disagreement with Griffin's position, but constituted a threat of physical violence as a possible escalation if he would continue to disregard community norms. In contrast to the public, carnivalesque group performances with effigies, the Griffin doll appeared anonymously overnight and remained hanging as a semi-permanent sign instead of being burned in an ephemeral symbolic performance. Although the performance appeared to express the majority position of the white community, it is unclear how many citizens actually supported the action: this kind of repressive effigy performance not only subjugates the minority group but also demands conformity from the majority group.

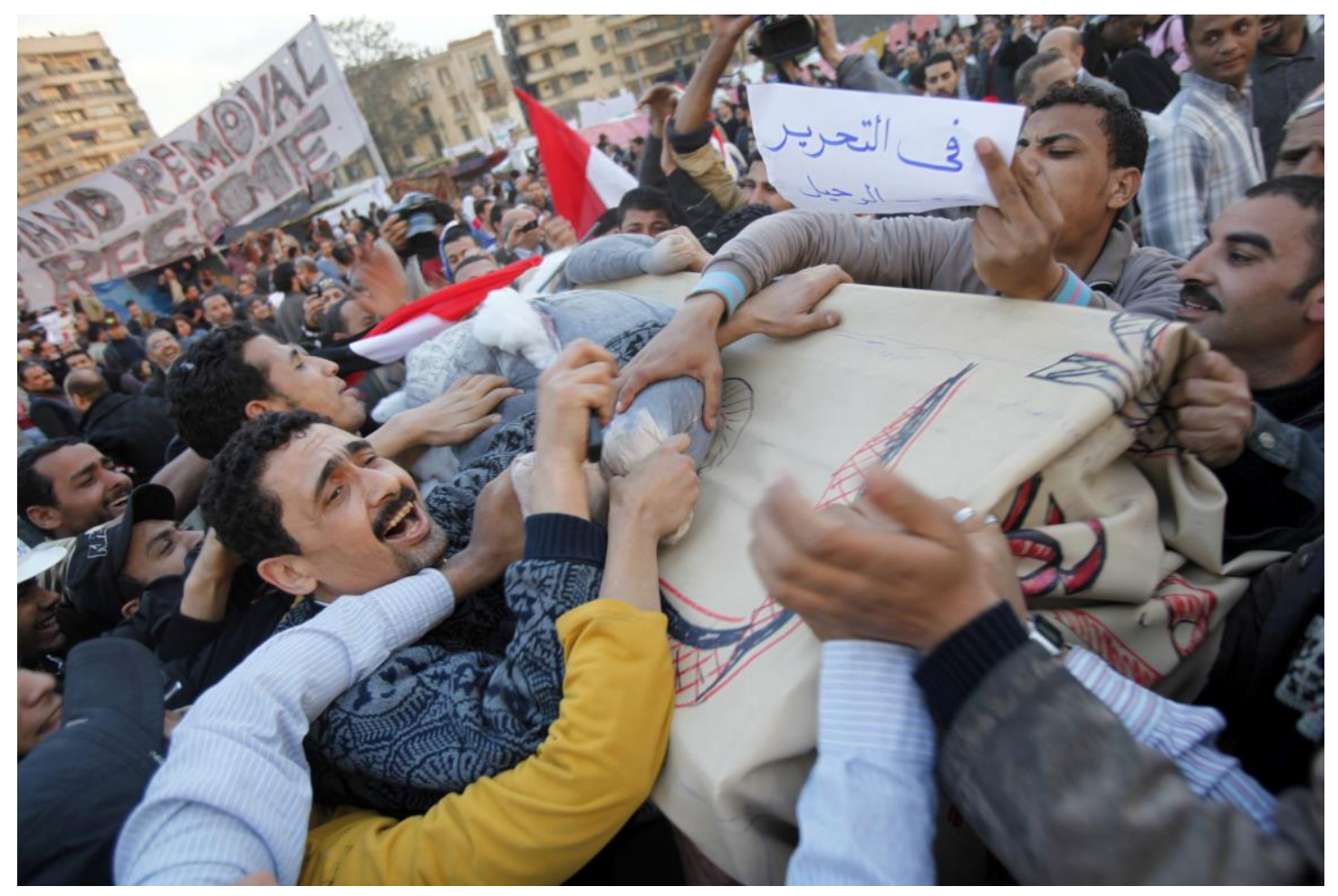

Figure 3. Mock Funeral of an Effigy of the Egyptian President Hosni Mubarak on Tahrir Square, Cairo, a week after the mass protests started (1 February 2011, Tahrir Square, Cairo, Egypt, photo: Asmaa Waguih / Reuters). 
The third mode of performing an effigy protest is based on the formal legal procedure of a trial, sentencing and execution, which is theatrically appropriated with an effigy acting in the role of the accused. In Figure 3 a group of jubilant men carry an effigy of the Egyptian President Mubarak lying upon a cloth-covered stretcher through the crowd on Tahrir Square in Cairo, while they seem either to be holding the effigy in place or in the midst of tearing it apart. Another photograph made earlier in the day shows three effigies of Mubarak being subjected to a mock trial. All three look quite the same: sewn and stuffed cloth bodies with painted grey suits, red buttocks and crotches. Mubarak's faces appear to be drawn with a thick marker, as are the red ties featuring the Star of David and the dollar bills sticking out of the effigies' drawn pockets. On the lower right side of the suits Mubarak's name is written in Arabic as if it were called out loud: "Mubaaaaaarak". After the mock trial, two of the effigies were hanged on the crossbeams of the traffic lights high above the crowd on Tahrir Square, one of which bore a sign in English: "The people want a trial for the murderous president." The third effigy (visible in Figure 3) was paraded on a stretcher through the crowd and ended up being torn to pieces.

The protesters in Cairo staged the mock trial, execution, and even funeral of Mubarak's effigy as a way to give their demands, the removal of the President from office, a legitimate, socially and politically accepted outlet. Just as with protests in the United States after the American Revolution described by Steven Wilf, here too in Egypt they used the "language of the law" to initiate a discussion about the basic principles of a just society and the legitimacy of Mubarak's regime (Wilf 2010: 1-5). Such performances replicate the ceremonial structure and language of the legal procedures, but do so in a parodic way. This is a carnivalesque doubling in Bakhtin's sense, which turns the world upside down, where the powerful, untouchable figure is dethroned, brought down to earth and literally within reach in the form of an effigy. The performances stage the alternative reality that the protesters demand and make it visible and imaginable (Schechner 1987: 124). It projects an image of the authoritarian ruler being subjected to the rule of law and the common will of the people. As a performance it aims to create group cohesion, to develop a group identity, and to expand support for the protest.

In practice, these three modes of effigy performances are not always as distinct. Already the practices they are derived from have certain characteristics in common. ${ }^{2}$ Furthermore, with each event, the demonstrators reinterpret, even reinvent the practices they access from shared cultural memory, which results in countless variations with close resemblances. The protests derived from carnival rituals and from formal legal procedures unfold and function in a particularly similar manner, as both build on the reversal of the existing order as the main strategy, and both progressively demand societal change. But they do activate different imaginations and associations and refer to different legitimizations - a celestial order as opposed to human justice. The more dissimilar mode is the effigy protest derived from popular justice, since it is enacted in a different constellation of dominance and subordination, and aims to repressively prevent change in society.

A sequence of photographs from 1957 that shows a group of white students in front of Little Rock High School in Arkansas, US, hanging, hitting and burning an effigy depicting a black student in protest against the desegregation of their school looks almost identical to a second sequence from 1972 showing white university students at the Southern Illinois University hanging, beating, and burning an effigy of President Nixon in protest of the Vietnam War. ${ }^{3}$ In both cases just a few people interact physically with the effigies while most members of the rather small audience keep their distance, some bearing bemused, some sceptical expressions. The crucial difference between these two actions is that just prior to abusing the effigy, the white 
students in Arkansas had stood in front of their high school, jeering and shouting threateningly at their actual targets - the nine African-American students that had to be escorted into the school under the protection of the National Guard. Therefore this effigy performance constituted a serious threat to the individual students as well as the local black community and was aimed to prevent changes in the unequal status of white and black citizens in the South. In the Nixon effigy case, the performance remained purely symbolic since this action conducted by a small group of university students demanding a change in US politics 840 miles away from the White House could hardly be considered a physical threat to the President of the United States.

Nevertheless, all three modes of effigy protest practice share important characteristics: they polarize two groups with opposing interests; they strengthen the identity and cohesion of the ingroup as well as the antagonized out-group, while they aim to garner support from any undecided segment of the community. In all three modes, debasement is the central strategy; they all exhibit the same grotesque aesthetics; and all are highly antagonistic through the use of personal attacks, humiliation, ridicule, and insults directed against the adversary's representative. In the following sections I will relate these commonalities in social effects, strategy, and aesthetics to Bakhtin's notion of the carnivalesque.

\section{Bakhtin's concept of the carnivalesque}

Bakhtin's carnivalesque is the description of a complex interlinked set of practices rather than a functional explanation of humour. He extrapolated his concepts of carnival laughter and the carnivalesque from the reading of early Renaissance novels, especially Rabelais' Gargantua and Pantagruel and projected them from there back into the Middle Ages, where carnival had "constitute[d] a second world parallel with the official world of seriousness" (1984a: 6). Bakhtinian carnival is an all-inclusive, communal celebration of cyclical time, which embraces change - death and rebirth - as necessary elements of life, placing particular emphasis on the basic bodily functions. The associated strategies of debasement and reversal, which establish a temporal alternative order, bestow carnival with inherently power-contesting traits: "This is why festive folk laughter [...] also means the defeat of power, of earthly kings, of the earthly upper classes, of all that oppresses and restricts" (1984a: 92).

Many critics have pointed out that carnival, as Bakhtin describes it, was never actualized anywhere. Other authors emphasize that carnival was not inherently furthering progressive change in society, and suggest that it functioned primarily as a temporary and licensed outlet for venting frustrations about social injustices, and in fact in the long term acted to stabilize the existing order. ${ }^{4}$ Later scholars proposed a more nuanced view that carnival and carnivalesque practices could have an effect on the social and political order in a variety of ways, either as affirming the social order, repressing dissent, or demanding and advancing change, depending on the constellation of participants, targeted entities, and the various audiences (Stallybrass \& White 1986: 14; Bruner 2005: 140; Crichlow \& Armstrong 2010: 406; Horlacher 2009: 25).

Indeed, Bakhtin's enthusiastic version of carnival probably never existed outside his imagination, as especially the supposedly all-inclusive nature of carnival laughter is hard to reconcile with many carnival traditions that employ their own mechanisms of inclusion and exclusion. But if we moderate Bakhtin's utopian inclusiveness to a more nuanced evaluation of carnivals' social effects, then his concepts can play an important role in theorizing carnival and carnivalesque practices as a space-time where the usual social order is suspended and possibilities to question the status quo emerge. (Chrichlow \& Armstrong 2010: 404.) 
In these temporal windows of opportunity, carnival and political protest become aligned. The celebration of cyclical time posits change as an integral and necessary aspect of life's continuous renewal. In the political protest, this necessity for change is translated into a demand for change, and the carnivalesque mutates from ritually marking change to symbolically demanding and even to actively advancing change. Because of this structural similarity, carnival proper and related traditional festivals often take on political issues, and traditional carnivalesque practices - of which some involve the use of effigies - are regularly appropriated for political protests. What is even more important for my argument is that the three basic elements of Bakhtin's carnivalesque combine into an interconnected assembly of the effects on the social body (inclusion and exclusion), a strategy (debasement and reversal), and an aesthetics (the grotesque), which in this combination is crucial for the interpretation of the protest effigy practice.

The first element is the suspension of social borders and the formation of a communal body through participation, which the practice shares with other forms of direct action and humorous protest strategies (Chvasta 2006: 12; Shepard 2010: 270). Similar to carnival, protests suspend normal life and institute liminal time and space, a communal space in which protesters lose the sense of distance from one another (Turner 1990: 8). A theatrical space emerges, where protesters take on roles in the public enunciation and enactment of protest, in which the act of burning effigies sometimes assumes a part. Similar to marching and chanting, the performance offers a physical communal experience. The protesters confront the physical likeness of the enemy as a group. They jointly participate in its playful destruction and through their action partially transform their anger into liberating carnival laughter. In the space of the protest there is no disinterested audience: all are participants, be they organizers, marchers or onlookers, and even the wider audience, reached through the media, is urged to take sides.

The second element is the strategy of reversal to create imaginaries of an alternative social and political order with the aim to foster change (Shepard 2010: 271). Hierarchies are theatrically turned upside down; the once sacrosanct leader is dethroned, insulted, and demonized. The effigy delivers the representative of power symbolically and literally into the hands of the formerly powerless protesters and they engage bodily in the performance of its destruction, screaming at it, hitting, punching, mutilating, and dismembering the doll until the "death" of the figure makes way for a "rebirth" within the previously corrupted political sphere (Hariman 2008: 254). While in carnival the suspension of fixed hierarchies is limited to the duration of the carnival season, in political protests the institutions of power are attacked in order to bring about permanent change.

The third element is the employment of a grotesque aesthetics, which I suggest appears as a consequence of both the strategy of reversal and the improvised mode of production. Debasement and demonization as expressed in a makeshift figure invariably produce dummies with deformed bodies, distorted expressions and insulting attributes and inscriptions. In connection with reversal, debasement, and demonization, Bakhtin stresses the relation of laughter "to the people's unofficial truth" (1984a: 90). The world turned upside down reveals the true and rightful social order, and this carnivalesque presentation of the truth opens up the space for political change. 


\section{Grotesque aesthetics}

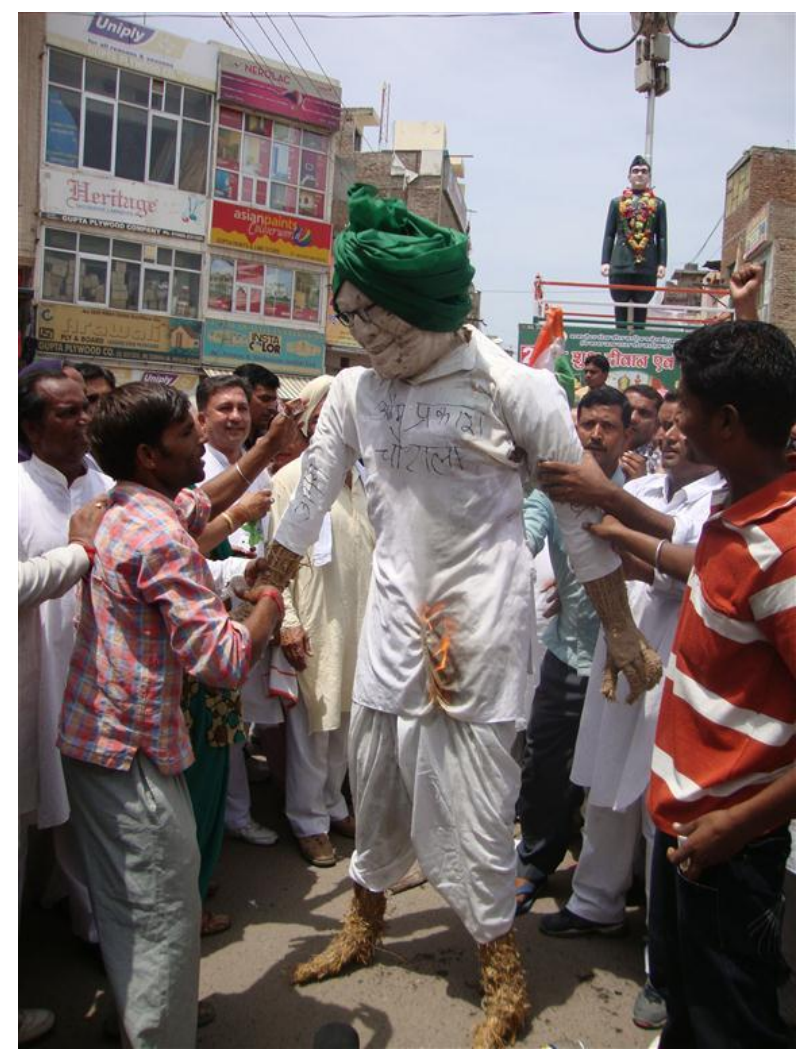

Figure 4. Leaders of the Congress Party burn an effigy of Om Prakash Chautala, leader of Indian National Lok Dal Party after he was indicted in a teacher recruitment scam (1 August 2011, Sonepat, Haryana, India, photo: Amar Singh Jyani).

In Figure 4 the effigy of the senior Indian politician Om Prakash Chautala stands in the centre of a small knot of protesters, in an urban area of Sonepat with three-storey buildings in the background. Behind the group a garlanded statue of Subhas Chandra Bose (a leading figure in the Indian independence struggle) looms over the crowd. ${ }^{5}$ The effigy in the foreground stands two heads taller than the surrounding protesters, supported by several outstretched hands in an almost tenderly supportive gesture. The effigy is beautifully made from straw and cloth, wearing Chautala's signature green turban and spectacles; his name is inscribed on the chest. Looking down benevolently in a seemingly intimate exchange with the protester facing "him", the effigy seems animated, almost alive. I would read the event as initiated to honour the effigy's prototype, were it not for the flame licking at the bottom edge of his shirt.

Effigies often evoke the uncanny feeling that they are alive and dead at the same time. Through the accidental movement of their limbs, they can give the impression of animated beings in one moment and reveal their inanimate nature in the next. The protesters' interactions with effigies tend to result in a sort of involuntary slapstick, wherein the roles of leader and follower sometimes seem reversed (Schechner 1987: 203). An effigy "put to death" by burning or hanging might evoke an eerie resemblance to an executed human corpse. In 1917, a local US 
newspaper describes the last moments of an effigy of the German Emperor Wilhelm II burned in Wisconsin, US: "The most spectacular feature was when the right arm, holding the sword, dropped in a most lifelike manner, the sword falling into the flames." (The Milwaukee Journal 1917) In this case, the lifelikeness seems to have made the performance more satisfying - as the effigy's fate resembled closely the one most audience members might have imagined deserving for the German Kaiser himself. But the uncanny similarity of the effigy execution with the execution of a living body and the violence of such images, might in other cases make the performance more repulsive and result in the inability to laugh.

Comparable to scarecrows, the effigies' usual mode of production places them in the realm of popular expressions. The makers of the effigies are most likely amateurs in the best sense of the word, lacking the necessary skills but enjoying the process of creating a life-size doll. Usually, these are made in an ad hoc, do-it-yourself manner, on the initiative of individuals or small groups. ${ }^{6}$ Consequently, the effigies are never naturalistic representations of their prototypes, but feature malformed anatomies with absurd bulges, dangling limbs, and distorted expressions. The figures invariable turn out to be grotesque, out of shape, indeed out of the control of their makers. Usually, a likeness is not even attempted. The effigy is designed to be grotesque and debasing to demonize, ridicule, and insult the prototype. It is supposed to reveal the evil traits that were once hidden behind the mask of the human being visible on the surface of the representation. In the eyes of the maker, the effigy unmasks the villain and reveals his/her true self.

Since digital images and the tools to print them have become widely available, photographic portraits of the adversary are often affixed to the effigy's head, resulting in hybrid "two-and-ahalf-dimensional" images. The use of a photograph-as-face enables recognition, but reduces the physicality of the dummy. In any case, the crucial issue for the effigy performance and its efficacy is not merely recognisability, but the unambiguous identification of the targeted personality. For that reason, the victim's name is usually inscribed onto the body of the effigy or on a sign attached to it. Added to it are often markers of the detestable nature of the depicted in its various contexts: swastikas and Stars of David, crossed-out faces, shoes (signifying insult), references to dogs, donkeys, apes and the lower bodily strata, vampire teeth and devils' horns. Imagine the "Killer of Muslims", a demon haunting Pakistani society, as a union of the US Presidents Bush and Obama in a single body with the face of a devil, and proudly presented to the camera by two young Pakistani men - actually one photograph in my collection. ${ }^{7}$ With the aim to be crystal clear about who is targeted and what is meant, the protesters create hybrid creatures that sometimes show an excess of signification.

In the performance of an effigy in protest, the grotesque is not just one of several possible aesthetics, but the unavoidable mode of representation, or as Stallybrass and White (1986: 23) put it: "The grotesque physical body is invoked both defensively and offensively because it is not simply a powerful image but fundamentally constitutive of the categorical sets through which we live and make sense of the world". These unwieldy dolls made from disjointed elements and too big to handle, are the monsters from our nightmares, who engage with their makers in a performance of slapstick and laughter but also of cruelty and repulsion. 


\section{Self-conscious performance}

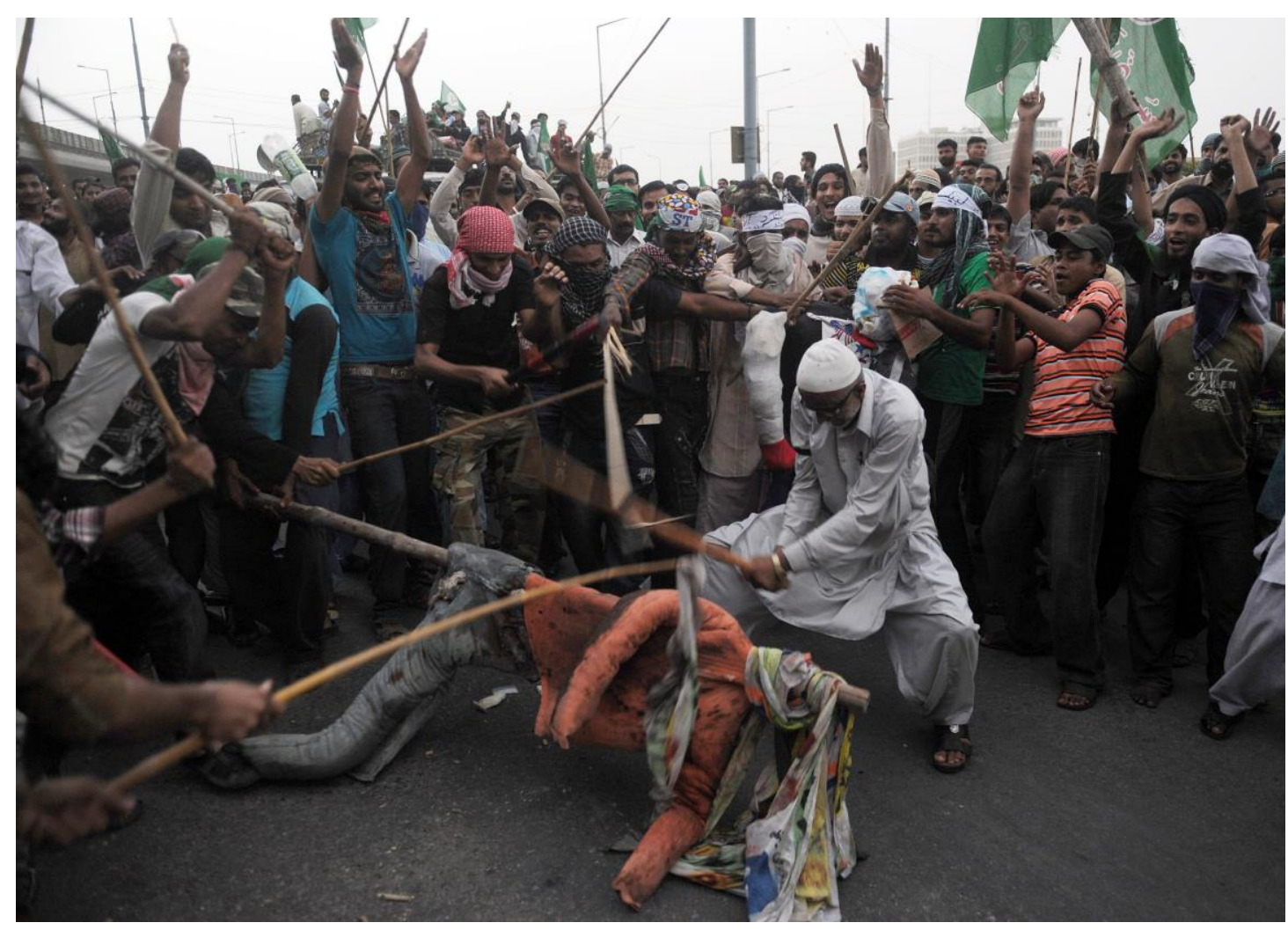

Figure 5. Protesters beat an effigy of US President Obama during a protest against the antiIslam film "Innocence of Muslims" (18 September 2012, Peshawar, Pakistan, photo: Rizwan Tabassum / AFP).

Looking at the photograph in Figure 5, we are facing what appears to be a large crowd of angry men at a demonstration against the anti-Islam film Innocence of Muslims in Peshawar. The protesters are grouped around an effigy of US President Obama on a pole that is lowered to the ground to facilitate the severe beating by seven or eight protesters with bamboo sticks. The effigy's legs are made from stuffed jeans and the upper torso and arms from orange cloth. The head is missing, but a colourful cloth is wrapped around the upper end of the pole. The protesters, mostly younger men, are carrying green flags, many are wearing headbands featuring slogans and some have covered their faces. They are in a rambunctious mood, clapping, laughing, shouting, and cheering on the effigy's beating. The photograph gives the impression of a large crowd with an abundance of energy, in a more celebratory than angry mood, and keenly aware of their power as a group in that moment. Their sense of power is gained through the realization of a fantasy, the violent beating of their adversary, in a reversal of roles, which suspends the usual feeling of violation and humiliation.

In many photographs of effigy protests the faces of the protesters show exhilaration and satisfaction: we can sense the maker's pride in a well-executed effigy, we see cheering and laughter caused by a playful theatrical performance. We can detect exhilaration amongst the crowd that the enemy is finally unmasked, that his true nature is unveiled and that the long- 
deserved punishment is finally meted out on the embodiment of the enemy. Staging the death of the almost-real embodiment of the enemy realizes the alternative reality that the protesters envision. At the same time it constitutes the symbolic conclusion - even though only temporary - of the injustices being protested against. We can also detect satisfaction about the success of the performance and the feeling of achievement of a common goal, which fuels a sense of community.

One can also notice the protesters' awareness of the ambiguity of the figure as being simultaneously just a doll and yet an almost real embodiment of the enemy, as self-conscious, ironic laughter sneaks into the faces of some actors. These participants seem to be aware of the absurdity of their action and the ridiculousness of engaging in a completely inconsequential performance, which one can interpret as the stubborn belief in the prevalence of subversive laughter even in the knowledge of likely defeat by an overwhelming state power. Knowing in advance that burning an effigy may fail to effect political change does not necessarily diminish the success of the performance. Rather it contributes to the carnivalesque spirit of encompassing death and rebirth, and a sense of vitality that is able to relinquish fear (Bakhtin 1984a: 90; Hariman 2008: 255).

On the other hand, there are actors who appear to be extremely serious going about executing the effigies, who attempt to quench all laughter from the performance in order to show the extent of their anger. But try as they might, they never fully succeed in quashing the ridicule with their seriousness. Bakhtinian laughter continues to seep through the cracks of their performance, at least in the mediated images, in which from a distance, the protesters and their protest can easily be judged as naïve, inept, and ineffective.

The effigy in Figure 5 is one of many of the US President Barack Obama burned in demonstrations in Afghanistan, Pakistan, and other Muslim countries, protesting a string of insults to Islam by the West. Although usually characterized as exercises of free speech, the intended Quran desecrations, the Muhammad cartoons, the movies Fitna and Innocence of Islam are all symbolic acts of violence, constructed as provocations of Muslim sensitivities. As much as the ensuing protests were directed at Muslim communities to demonstrate communal outrage, they also aimed to communicate to a Western audience. The effigy practices were actively used as tools for cross-cultural communication to express frustration and anger, as well as to demonstrate the depth of Muslim piety and the severity of the insults. But in the process of mediation, the protesters lose control over the interpretation of their actions. Although legible and recognizable, the meanings of these images change when they enter a different social, geographic, and temporal context (Erll 2011: 11). Moreover, in the media they are invariably framed for a variety of purposes and seldom in line with the protesters' intentions.

Afghani and Pakistani protesters are generally characterized in the Western media as unreasonable, aggressive, and excessively violent, or alternatively as unreasonable, humourless, and childish. Implicitly and often explicitly, the protesters are portrayed as incapable of engaging in democratic discourse - even though burning an effigy is after all a peaceful, symbolic expression of political discontent. In this dynamic of intentional misreading, the honour of Islam appears in existential conflict with the equally sacrosanct Western value of free speech.

\section{Conclusion: carnivalesque laughter and violence}

Baz Kershaw argues that the turn towards theatrical strategies in protests in the 1960s, "opened up a much wider perspective on the potential of protest: in a sense the imaginary became more 
important than the possible, and the visionary more persuasive than the rational" (1997: 265). Based on my own research, I would suggest that playful, symbolic strategies have always been employed in political protests alongside more serious, discursive ones, and, of course, more violent ones. Kershaw argues further that "the whole purpose of much contemporary protest has been to achieve efficacy by inventing unprecedented symbolic-real configurations" (1997: 266). But efficacy is both an elusive goal and one that is hard to define. A performance can be successful as a unifying event, energizing the protesters at a rally, but how should we gauge its effect in political terms? A week after the mock trial of his effigies on Tahrir Square in February 2011, President Mubarak resigned and six months later he was facing trial in a real courtroom in front of a real judge. But alas, another two and a half years later, we saw a new military dictator climbing the Egyptian throne. Are we back to the old Egypt? Or has the Egyptian people's imaginary changed thoroughly enough to have a lasting effect on Egypt's political system?

The questions remain as to who is laughing and whether these effigy hangings and burnings are reason for laughter at all? If we imagine these symbolic acts literally, if we recognize the resemblance with tormented, mutilated bodies and allow the associations with executions and lynching, if the carnivalesque laughter in the performance is drowned out, these images become dubious and repulsive, and certainly no laughing matter. The grotesque effigy executions can be crass, demeaning, and insulting. They state political discontent in an extreme way, suggesting a violation of the victim's body as well as his/her honour, and they transgress the etiquette of everyday political discourse. But sometimes exactly that kind of transgression might be needed to adequately express the anger over government politics.

In this essay, I sought to trace the different expressions of the carnivalesque that are apparent in the photographs of the performances. An effigy protest can be enacted in different modes and on each occasion laughter emerges in different ways and to different degrees and is highly dependent not just on the position of each actor but also on his/her disposition. To make things even more complicated, one could equally attempt to trace in such photographs the inability to laugh in the face of a repulsive and insulting image, or the "unlaughter", the refusal to laugh in order to emphasize the seriousness of the transgression (Smith 2009: 151). ${ }^{8}$

Despite all provisions, effigy protests appear as communal performances with all the elements that Bakhtin ascribes to carnival: the placement outside of daily life, the strategies of reversal and debasement, the relation to truth, and the unifying and liberating effects of laughter - even though the laughter retains its unifying properties only for one group in the conflict, and it is often difficult to detect, where the peaceful symbolic action turns into a threat and amounts to an actual act of violence towards the opposing group.

The suspension of a fixed meaning allows for a wide range of actualizations and leaves the possibility to shift the emphasis from playful laughter to violent anger even in the course of the performance. And maybe this ambiguity is wilfully left open by both sides. As a rhetorical means in the political struggle, both sides can use the ambiguity for the modulation of their position. The protesters have the option to ameliorate their claim by stressing the humorous and symbolic nature of their action or assert an aggressive position by emphasizing the threat, while the "victims" have the options to express outrage over the violent demonstration or ridicule the naïve and inconsequential act of the demonstrators.

In examining the performance of effigy burnings in political protests, we find ambivalence on all levels, not in mutually exclusive binaries but bound in an unstable and contradictory relationship of these opposites: the doll seems alive and dead at the same time, laughter is coupled with violence and repulsion. The effigy performance is effective in many ways: in 
providing a captivating performance, in enhancing group cohesion and in reaching a wide audience, but ineffective in delivering a straightforward message, and on its own, inept at effecting lasting political change. It has unifying as well as antagonizing effects, and can affect the social and political sphere progressively as well as repressively. Which brings us back to Bakhtin, who reminds us in Problems of Dostoevsky's Poetics "Deeply ambivalent also is carnival laughter itself (1984: 126)."

\section{Notes}

${ }^{1}$ Just to name a few examples: traditional Spanish seasonal celebrations were established and are still practiced all over Latin America as well as in parts of the Philippines, where they were transformed into an especially vibrant part of Filipino protest repertoire since the 1990s. Guy Fawkes' Day was introduced by the British in its colonies in New England, and in turn was re-appropriated during the American Revolution to rally against British rule.

${ }^{2}$ Carnival and popular justice are often discussed as related practices in anthropological and folklore studies (Muir 1997, Bakhtin 1984a, Rooiakkers 1995). Popular justice and formal justice influence each other substantially and both are mechanisms to maintain the established order (Wilf 2010, Pfeifer 2011).

${ }^{3}$ First series of photographs: Bettman/Corbis, 4 October 1957, Little Rock, Arkansas, USA; second series of photographs: Lawrence Roth, spring 1972, Southern Illinois University, Springfield, Illinois, USA.

${ }^{4}$ For a detailed discussion of this dispute, see the introduction to The Politics and Poetics of Transgression by Peter Stallybrass and Allon White (1986).

5 The presence of these two representations seems to confirm the hypothesis attributed to the $17^{\text {th }}$ century French scholar of penal politics Pierre Ayrault that with an image one can equally honour and dishonour a person. But I would argue against this symmetry, since creating someone's image usually reflects positively on the prototype. It does not need a garland to make an image honorific, but it does need a specific effort of debasement to make an image disparaging.

${ }^{6}$ In countries with traditional rituals involving the burning of effigies, for instance in India or Latin America, there are workshops and artisans specialized in effigy-making and indeed sometimes they are employed to make effigies for use in political protests as well. Judging from the materials used, the level of skill involved, as well as by the proportional and smart-looking results, I suspect that the effigy of Om Prakash Chautala in Figure 4 was made by a professional effigy-maker.

${ }^{7}$ AP Photo by Shakil Adil, 18 Sep 2009, Karachi, Pakistan. The effigy bears the lettering: "The Killer of Muslims - Bush \& Obama".

8 The term "unlaughter" was originally coined by Michael Billig (2005) as the "rhetorical opposite of laughter [...] in the processes of learning and imposing the disciplines of social life". Moira Smith (2009) applies "unlaughter" more specifically to the construction of social boundaries, which I am dealing with in this article.

\section{References}

Bakhtin, M. (1984a [1941]). Rabelais and his World. Indianapolis: University of Indiana Press. 
Bakhtin, M. (1984b). Problems of Dostoevsky's Poetics. Minneapolis/London: University of Minnesota Press.

Billig, M. (2005). Laughter and Ridicule: Towards a Social Critique of Humour. London: Sage Publications.

Bruner, M. L. (2005). 'Carnivalesque protest and the humorless state', Text and Performance Quarterly 25 (2), pp. 136-155.

Crichlow, M. A. \& Armstrong, P. (2010). 'Carnival praxis, carnivalesque strategies and Atlantic interstices', Social Identities 16 (4), pp. 399-414.

Chvasta, M. (2006). 'Anger, irony, and protest: Confronting the issue of efficacy, again', Text and Performance Quarterly 26 (1), pp. 5-16.

Edwards, E. \& Morton, C. (2009). 'Introduction', in Edwards, E. \& Morton, C. (eds.), Photography, Anthropology and History. Surrey: Ashgate, pp. 1-24.

Erll, A. (2011). 'Travelling memory', Parallax 17 (4), pp. 4-18.

Ferguson, M. A. and Thomas, E. F. (2008). 'Disparagement humor: A theoretical and empirical review of psychoanalytic, superiority, and social identity theories', Humor 21 (3), pp. $283-$ 312.

Griffin, J. H. (2004 [1960]). Black Like Me. San Antonio: Wings Press.

Hariman, R. (2008). 'Political parody and public culture', Quarterly Journal of Speech 94 (3), pp. 247-272.

Horlacher, S. (2009). 'A short introduction to theories of humour, the comic, and laughter", in Pailer, G., Böhn, A., Horlacher, S. \& Scheck, U. (eds.), Gender and Laughter - Comic, Affirmation and Subversion in Traditional and Modern Media. Amsterdamer Beiträge zur neueren Germanistik 70. Amsterdam: Rodopi, pp. 17-47.

Kershaw, B. (1997). 'Fighting in the streets: Dramaturgies of popular protest, 1968-1989', New Theatre Quarterly 13 (51), pp. 255-276.

The Milwaukee Journal (1917). 'Burn effigy of the Kaiser', 21 October 1917. Available online: http://news.google.com/newspapers?nid=1499\&dat=19171021\&id=4xAaAAAAIBAJ\&sjid= FSEEAAAAIBAJ\&pg=2535,6543344 [Accessed 16 August 2013].

Muir, E. (1997). Ritual in Early Modern Europe. Cambridge: Cambridge University Press.

Pfeifer, M.J. (2011). The Roots of Rough Justice: Origins of American Lynching. Urbana: University of Illinois.

Rooiakkers, G. (1995). Eer en schande - Volksgebruiken van het oude Brabant. Nijmegen: SUN.

Schechner, R. (1987). Performance Studies. An Introduction. London: Routledge.

Shepard, B. (2010). Queer Political Performance and Protest. Play, Measure and Social Movement. New York: Routledge.

Smith, M. (2009). 'Humor, unlaughter, and boundary maintenance', Journal of American Folklore 122 (484), pp. 148-171.

Stallybrass, P. \& White, A. (1986). The Politics and Poetics of Transgression. New York: Cornell University Press.

Thompson, E.P. (1992). 'Rough music reconsidered', Folklore 103 (1), pp. 3-26.

Turner, V. (1990). 'Are there universals of performance in myth, ritual and drama?', in Schechner R. \& Appel, W. (eds.), By Means of Performance. Cambridge: Cambridge University Press, pp. 8-18.

Wilf, S. (2010). Law's Imagined Republic. Popular Politics and Criminal Justice in Revolutionary America. Cambridge: Cambridge University Press. 